\title{
Response of Soybean to Fertilizer Levels in Northern Dry Zone of Karnataka, India
}

\author{
Vijayalakshmi Patil", Shankar Meti, M. S. Nagaraja, E. Rajashekar and C. P. Mansur
}

University of Horticultural Sciences, Bagalkot-587104, Karnataka, India

*Corresponding author

\begin{tabular}{l} 
K e y w o r d s \\
$\begin{array}{l}\text { Vegetable soybean, } \\
\text { internal nutrient use } \\
\text { efficiency, nutrient } \\
\text { uptake, Fertilizer level }\end{array}$ \\
Article Info \\
\hline $\begin{array}{l}\text { Accepted: } \\
28 \text { April } 2018 \\
\text { Available Online: } \\
\text { 10 July } 2018\end{array}$
\end{tabular}

\section{Introduction}

Vegetable soybean has excellent potential for enriching the human diet. Vegetable soybean is rich in protein $(13 \%)$, cholesterol-free fatty acids $(57 \%)$, TSS (6.5\%), phosphorus (158 $\mathrm{mg} / 100 \mathrm{~g})$, calcium $(78 \mathrm{mg} / 100 \mathrm{~g})$, It is a good source of carbohydrate and iron rich source of vitamin $\mathrm{A}$, vitamin $\mathrm{B} 1(0.4 \mathrm{mg} / 100 \mathrm{~g})$ and vitamin $\mathrm{B} 2(0.17 \mathrm{mg} / 100 \mathrm{~g})$. In addition it is a natural source of iso-flavones and tocopherols. The nutritional value and protein content is an important characteristic of vegetable soybean,
The nutrient value and protein content of vegetable soybean makes excellent source for enriching human diet. However the productivity and production of vegetable soybean is low due to lack of nutrient management specific to vegetable soybean leading to considerable variability in yield and quality. In this regard an experiment was conducted to study the response of vegetable soybean to fertilizer levels in northern Karnataka. Fertilizer levels significantly the nutrient uptake with 125 per cent Recommended Dose of Fertilizer (RDF) recording significantly higher nutrient uptake particularly vegetable soybean Swarna vasundhara. However JS 335 showed significantly higher K uptake resulting in pod number and Harvest Index (HI). Sustainable nutrient management must be efficient and effective. Increased level of fertilizer resulted in increased nutrient uptake by Swarna vasundhara, but internal nutrient utilization (IE) was low compared to JS 335 indicating the nutrient imbalance or other stresses. Among the treatments JS 335 with 125 per cent RDF recorded maximum post-harvest soil nutrient status with positive net gain indicating the balanced nutrient for soil health sustainability. On the other hand Swarna vasundhara with all the fertilizer levels showed low post harvest soil nutrient status with negative net gain for all nutrients indicating the need for evolving the separate fertilizer dose for vegetable soybean for the northern dry zone of Karnataka. which is superior to the meat, cow milk and eggs. Vegetable soybean provides more protein of higher quality and is considered as excellent protein source compared to vegetable pigeon pea and green peas protein. In addition to domestic consumption, vegetable soybean also has export potential. Vegetable soybean pods are harvested at the completely seed filled stage while pods and plants are still green.

The productivity and production of seed crop is low, due to lack of proper management 
practices, among which nutrient management is one of the major factor which helps in mitigating the scarcity of nutrients. This accounts for considerable variation in pod quality and yield parameters. Proper nutrient management is one of the major factors for increasing the percentage of nutrients availability in the soil which influences better growth and development of the crop. Tremendous variation in nutrient availability to the crop results in lower yield, reduced crop development and also affects physiology of the crop. In this direction no such studies are being conducted in India particularly in Karnataka. Hence the need for study on the performance of vegetable soybean under the agro-climatic condition of northern Karnataka with varied levels of fertilizer dose was felt and experiment was proposed with objective of studying the response and nutrient use efficiency of vegetable soybean visa a vis seed soybean to varied level of fertilizer.

\section{Materials and Methods}

The present investigation on "Nutritional studies on vegetable soybean in northern dry zone of Karnataka" was conducted at Main Horticulture Research and Extension Centre, UHS, Bagalkot situated in northern dry zone of Karnataka at $16^{\circ} 12^{`}$ North latitude, $75^{\circ} 45^{`}$ East longitude and an altitude of 610 meters above the mean sea level. The soil of experimental site was Red sandy loam in texture. The climate is warm and dry throughout the year and rain fall is scarce. During crop period i.e., from July 2016 to October 2016 the rainfall received was low (198 mm). Mean maximum and minimum relative humidity were 64.70 and 79.25 per cent, respectively. The maximum and minimum temperature was $29.5^{\circ} \mathrm{C}$ and $20.25^{\circ} \mathrm{C}$. Experiment consisted of Factor I as variety (JS 335 and Swarna vasundhara) at two levels and Factor II as fertilizer dose (125 per cent Recommended dose of Fertilizer
(RDF), 100\%, 75\%, 50\% RDF and 100\% Recommended dose of nitrogen through organic manure) at 5 levels with total of 10 treatment combination laid out in RBD design with three replications. Recommended dose of fertilizer for seed soybean (40:80:25:12:20 kg $\mathrm{N}: \mathrm{P}_{2} \mathrm{O}_{5}: \mathrm{K}_{2} \mathrm{O}: \mathrm{ZnSO}_{4}$ : S per hectare) was used for treatment wise fertilizer requirement calculation (UAS Dharwad, 2016). Spacing adopted was $30 \times 10 \mathrm{~cm}$ with gross plot size of $2 \times 2 \mathrm{~m}$. Irrespective of treatment, seeds were treated with Rhizobium + PSB @ 1.25kg/ha. Pre and post experiment soil sample was collected from $30 \mathrm{~cm}$ depth and analysed for N,P and K nutrients (Subbaiah and Asija, 1956; Jackson, 1973 ; Walkley and Black 1934) and worked out balance nutrient content in soil. Recorded total dry matter (TDM) production per plant at harvest and estimated major nutrient content in leaf, stem and pod following the method (Piper, 1966). Internal utilization efficiency of major nutrient was calculated using the formula as given by Doberman (2007) and expressed in $\mathrm{kg}$ yield/kg nutrient.

$\mathrm{IE}=\frac{Y}{U}$

Where,

$\mathrm{Y}=$ Yield of harvested portion of crop $(\mathrm{kg})$.

$\mathrm{U}=$ total nutrient uptake in aboveground crop biomass ( $\mathrm{kg})$.

\section{Results and Discussion}

\section{Uptake of nutrients}

Fertilizer levels, varieties and their interactions significantly influenced total uptake of $\mathrm{P}$ and $\mathrm{K}$ (Table1). Total uptake of $\mathrm{N}$ was significantly influenced by fertilizer level and verities only but their interaction did not. Among the varieties Swarna vasundhara 
recorded significantly higher uptake of nitrogen and phosphorus over JS-335 but K uptake was significantly higher with JS 335. Among the fertilizer levels, the application of 125 per cent RDF recorded significantly higher uptake of nitrogen, phosphorus and potassium over other treatments. With regard to interaction, application of 125 per cent RDF with Swarna vasundhara recorded significantly higher uptake of phosphorus whereas JS 335 recorded higher potassium over all other treatment combinations.

Application of 125 per cent RDF recorded significantly higher $\mathrm{N}$ and $\mathrm{P}$ uptake compared to other levels. High level of fertilizer resulted in maximum nutrient uptake due to significant increase in photosynthesis, root development and microbial activity. The high level of phosphorous resulted in the maximum uptake of NPK due to close association of $\mathrm{N}$ and $\mathrm{P}$ in the process of metabolism in plant cells. Significant effect of fertilizer level and variety on growth parameters of soybean has been reported (Patil et al., 2017) and similarly significant positive correlation of nutrient uptake with growth parameters like number of leaves, LAI and plant height has been observed (Table 2). These results corroborated the findings of Prasad and Sanoria (1981), Sharma and Dixit (1987), Meena et al., (2006), and Vyas and Kushwah (2015). Among the variety, Swarna vasundhara recorded significantly higher uptake of $\mathrm{N}$ and $\mathrm{P}$ compared to JS 335. This may be due to significantly higher nutrient content in leaves and stem resulting in significantly higher $\mathrm{N}$ and $P$ uptake (Fig 1-2). This is reflected in the significant positive correlation between stover yield and $\mathrm{N}(\mathrm{r}=0.92)$ and $\mathrm{P}(\mathrm{r}=0.89)$ uptake. However JS 335 recorded significantly higher K uptake compared to Swarna vasundhara. This may be because JS 335 has showed higher $\mathrm{K}$ content in pod (Fig 3) and produced more number of pods and $\mathrm{K}$ is known to play a major role in translocation of photosynthates from source to sink and hence recorded significantly higher HI. (0.61). Potassium is known to promote the conversion of plant metabolites into proteins and amino and this is evident from significant positive correlation of $\mathrm{K}$ uptake with protein content $(\mathrm{r}=0.66)$.

\section{Internal utilization efficiency of nutrients}

Phosphorus and potassium internal use efficiency was significantly influenced by variety, fertilizer levels and their interaction but nitrogen internal use efficiency was not significantly influenced by interaction between variety and fertilizer levels (Table 3). Among the varieties JS-335 recorded significantly higher internal utilization efficiency of nitrogen $(56.3 \mathrm{~kg} / \mathrm{kg})$, phosphorus $(433.18 \mathrm{~kg} / \mathrm{kg})$ and potassium $(20.66 \mathrm{~kg} / \mathrm{kg})$ over Swarna vasundhara. Among the fertilizer levels, application of 50 per cent RDF recorded significantly higher internal utilization efficiency of nitrogen $(54.39 \mathrm{~kg} / \mathrm{kg})$ and phosphorus $(355.82 \mathrm{~kg} / \mathrm{kg})$ but 75 per cent RDF recorded significantly higher internal utilization efficiency of potassium $(20.03 \mathrm{~kg} / \mathrm{kg})$. With regard to interaction JS 335 with applications of 50 per cent RDF recorded significantly higher internal utilization efficiency of phosphorus (546.87 $\mathrm{kg} / \mathrm{kg}$ ) whereas 75 per cent RDF recorded significantly higher internal utilization efficiency of K $(24.67 \mathrm{~kg} / \mathrm{kg})$.

Sustainable nutrient management must be both efficient and effective and is greatly impacted by fertilizer management. Nutrient use efficiency (NUE) determines the sustainability of fertilizer management practices. In this regard Internal utilization Efficiency (IE), a measure of NUE determine the yield in relation to total nutrient uptake. It varies with genotype, environment and management. A very high IE suggests deficiency of that nutrient. Low IE suggests poor internal nutrient conversion due to other stresses 
(deficiencies of other nutrients, drought stress, heat stress, mineral toxicities, pests, etc.). Increase in fertilizer level has lead to increased uptake of nitrogen, phosphorus and potassium nutrients resulting in increased yield as evident from positive trend observed between nutrient uptake and yield for $\mathrm{N}$ and $\mathrm{P}$ in JS 335 variety but Swarna vasundhara failed to show such relation (Fig 4-5). Even though uptake of nutrient by Swarna vasundhara was significantly more compared to JS 335 but Swarna Vasundhara failed to efficiently utilize the absorbed nutrient particularly $\mathrm{N}$ and $\mathrm{P}$ and same thing is evident by low IE observed in Swarna vasundhara (25.5 and $138.1 \mathrm{~kg} / \mathrm{kg}$ ) compared to JS 335 (56.3 and $433.2 \mathrm{~kg} / \mathrm{kg}$ ) respectively. The poor internal nutrient conversion in Swarna vasundhara can be attributed to imbalance in nutrient or may be due to drought/heat stress.

During 2016-17 rainfall received in northern part of Karnataka was less than normal and average maximum temperature was $29.5^{\circ} \mathrm{C}$ which might have caused heat stress leading to poor nutrient conversion. Moreover vegetable soybean variety Swarna vasundhara comes up well in humid climate with acidic soil $\mathrm{pH}$, but the northern part of Karnataka is dry land with alkaline soil $\mathrm{pH}$. The seed soybean variety JS 335 is bred for this region and is well adapted to this regions climate and soil. Internal use efficiency of absorbed nutrient was comparatively better in JS 335 compared to Swarna Vasundhara and hence its performance was better.

Among the fertilizer levels, 125 per cent RDF showed significantly higher $\mathrm{N}, \mathrm{P}$ and $\mathrm{K}$ nutrient uptake but with respect to IE, 100 per cent RDF showed better efficiency for all nutrients compared to 125 per cent RDF. With 25 per cent increase in fertilizer level over RDF there was a decline in nitrogen internal use efficiency from $62.3 \mathrm{~kg}$ pod $/ \mathrm{kg} \mathrm{N}$ to 41.7 $\mathrm{kg}$ pod $/ \mathrm{kg} \mathrm{N}$ indicating the imbalance or deficiency of other nutrients for efficient utilization of increased $\mathrm{N}$ uptake. Similar trend was observed for $\mathrm{P}$ and $\mathrm{K}$ nutrient also. As per the Blackmans Law of limiting factor, there is a need to remove the limiting factor to enhance the internal utilization efficiency of absorbed nutrients and hence further investigations are needed in this direction to enhance the nutrient use efficiency as well as the yield also.

Fig.1 Effect of varieties and fertilizer levels on nitrogen content in different plant parts

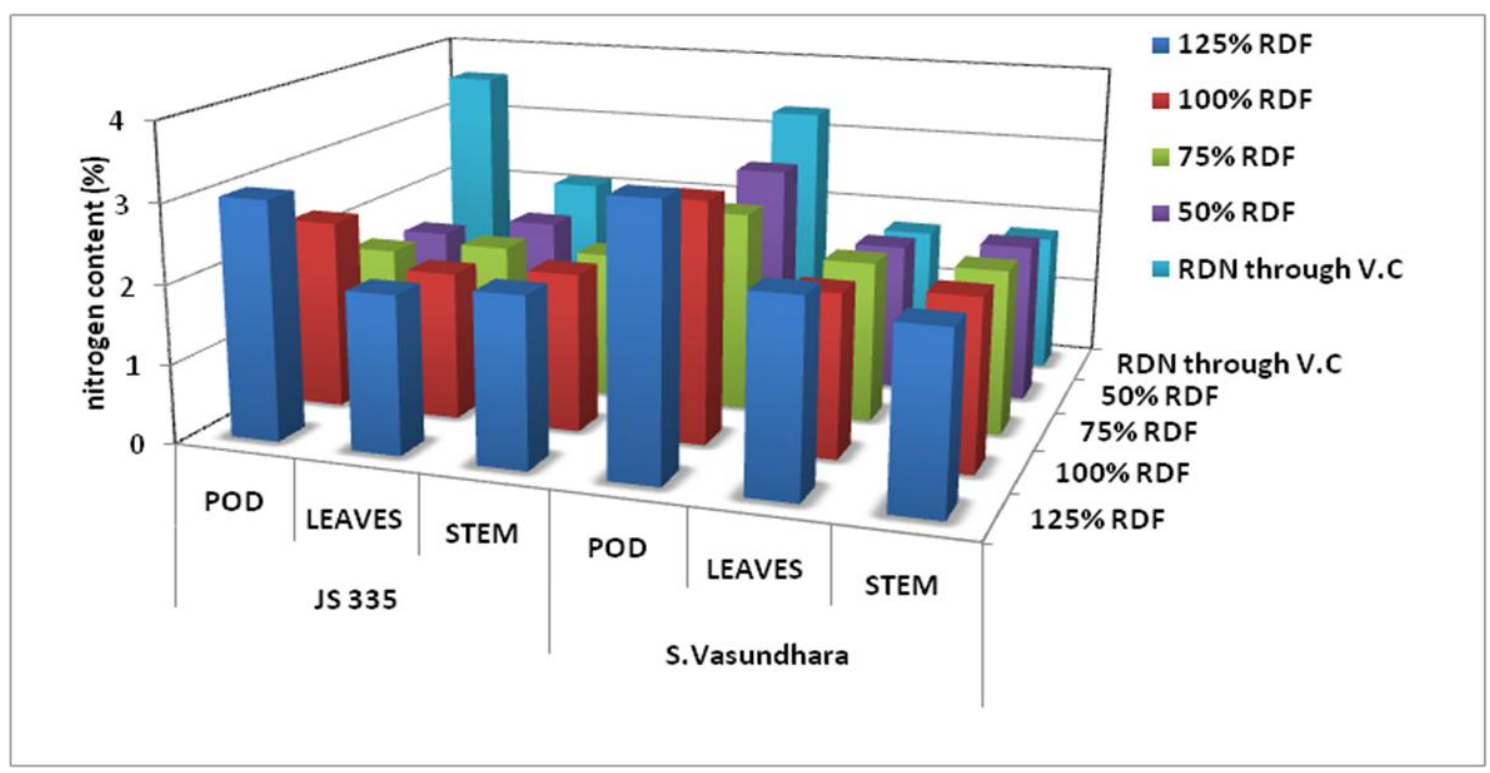


Fig.2 Effect of varieties and fertilizer levels on phosphorus content in different plant parts

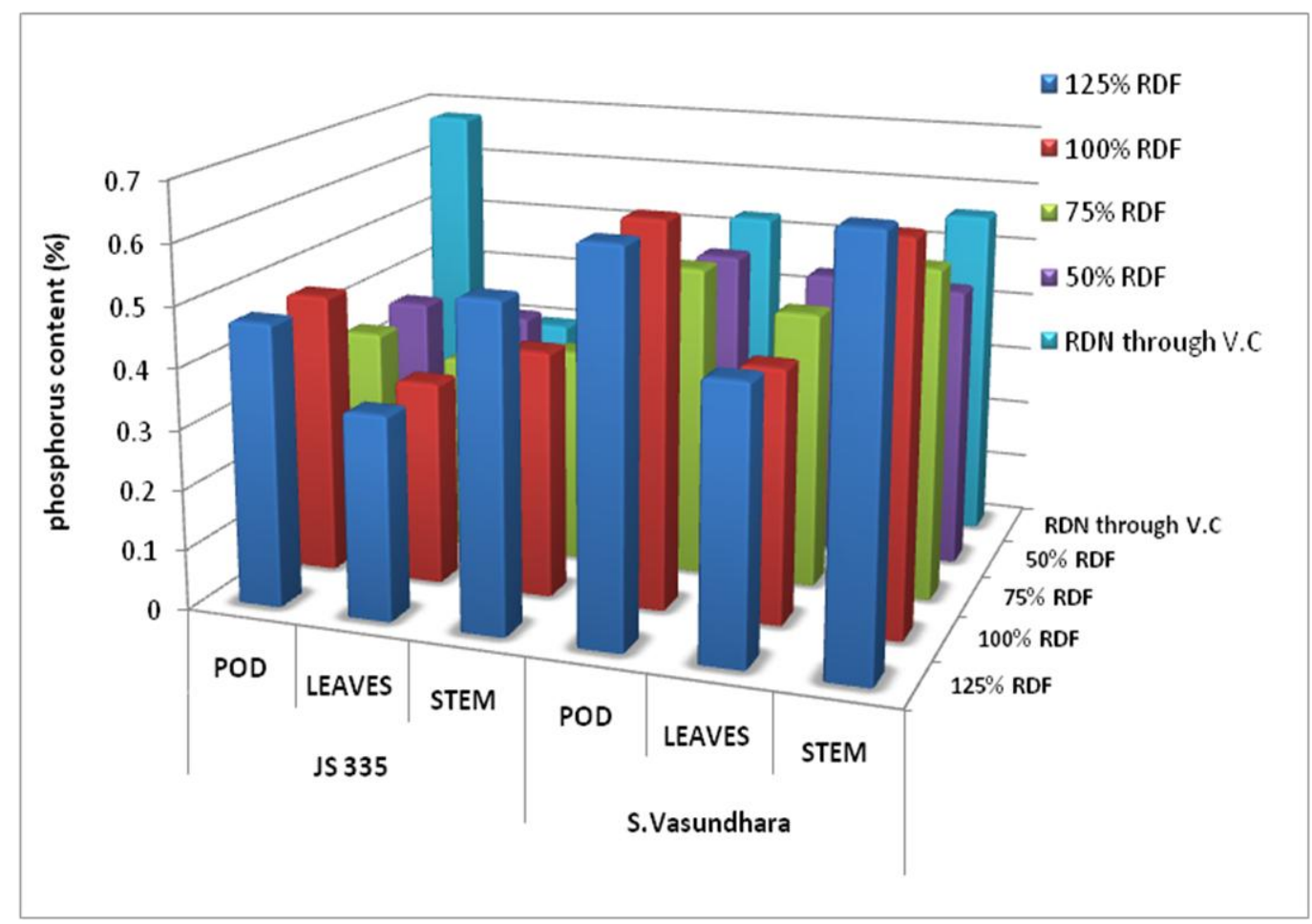

Fig.3 Effect of varieties and fertilizer levels on potassium content in different plant parts

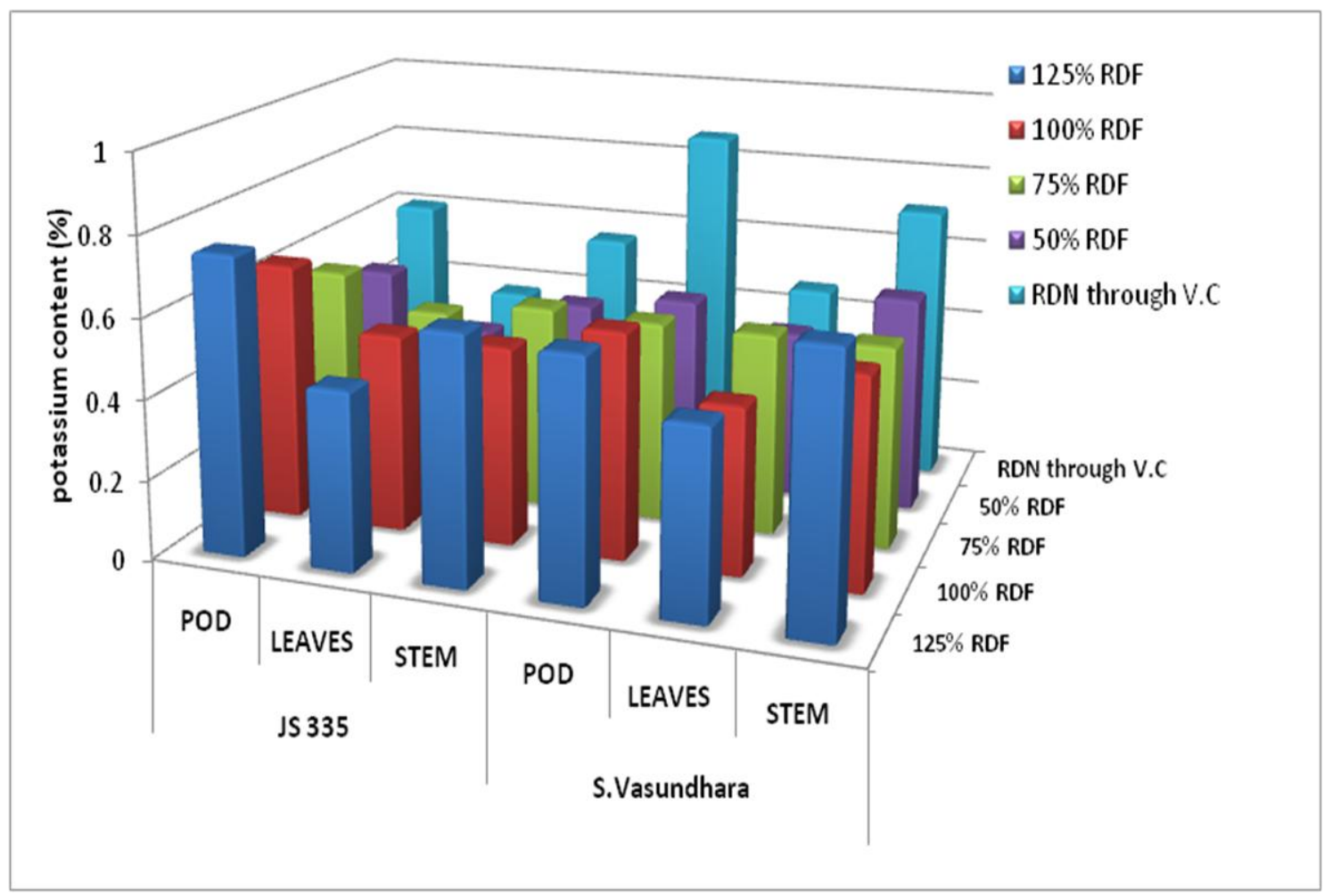


Fig.4 Pod yield vs nitrogen uptake

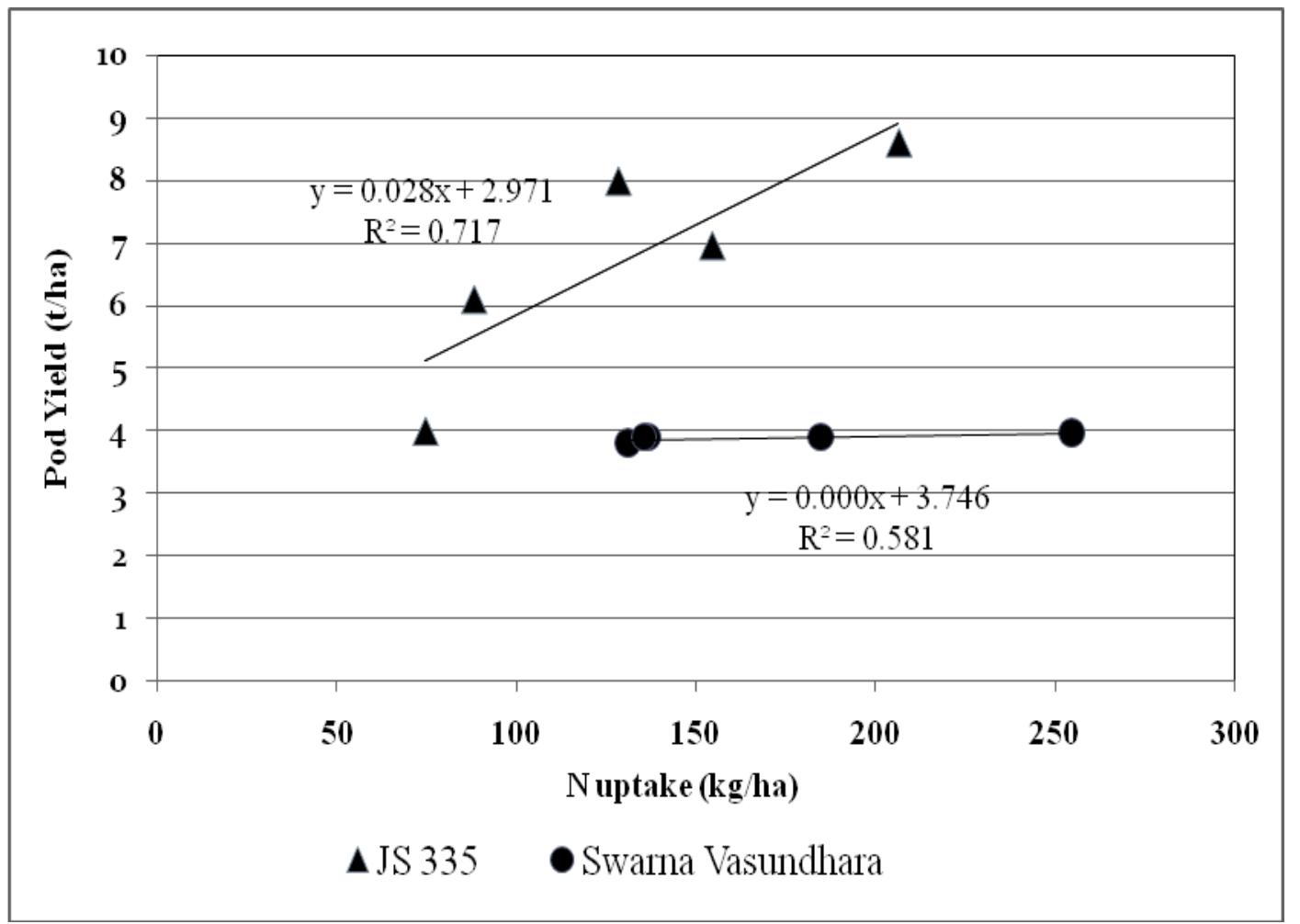

Fig.5 Pod yield vs Phosphorous uptake

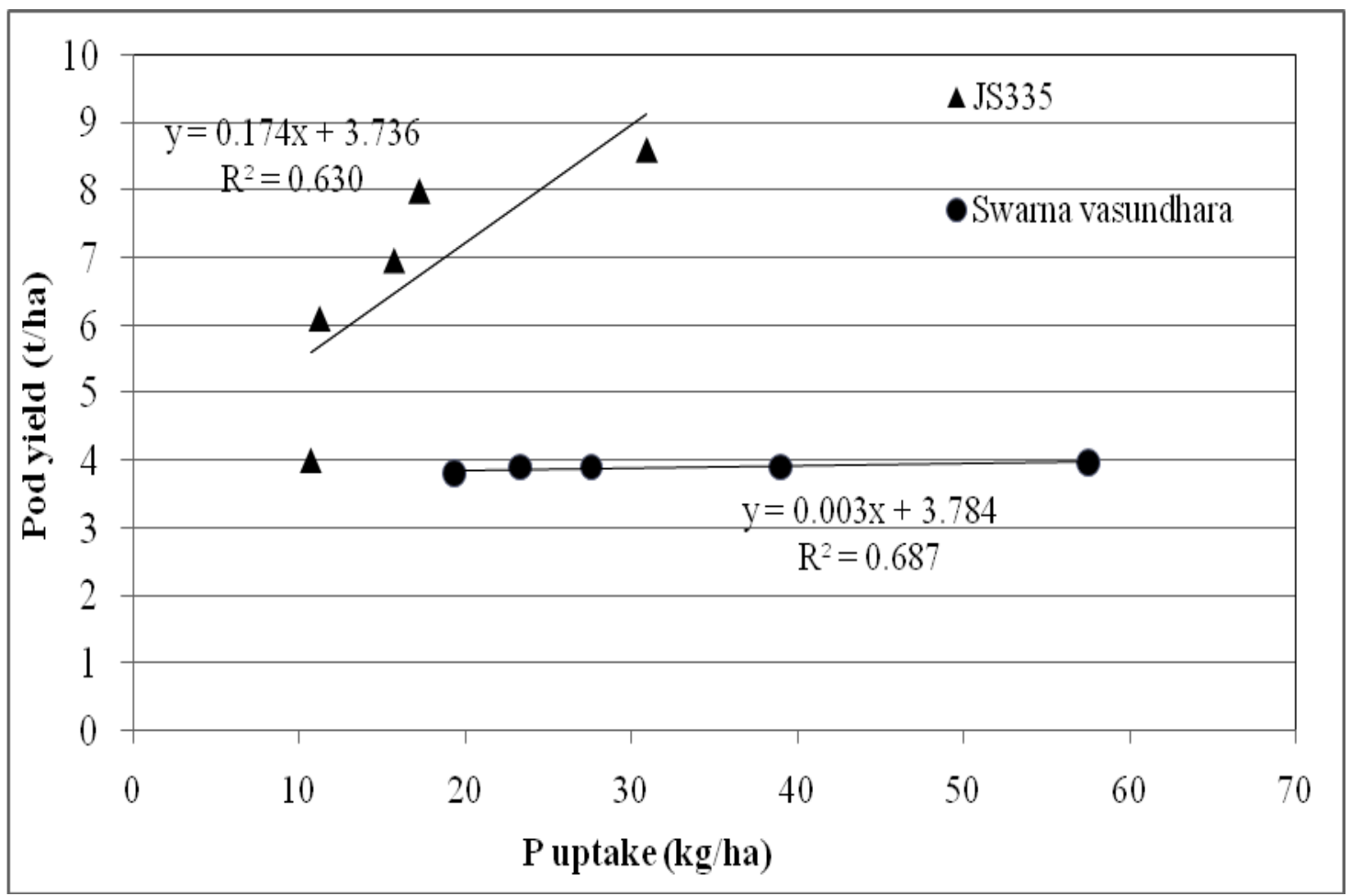


Table.1 Effect of varieties and fertilizer levels on total uptake of nitrogen, phosphorus and potassium

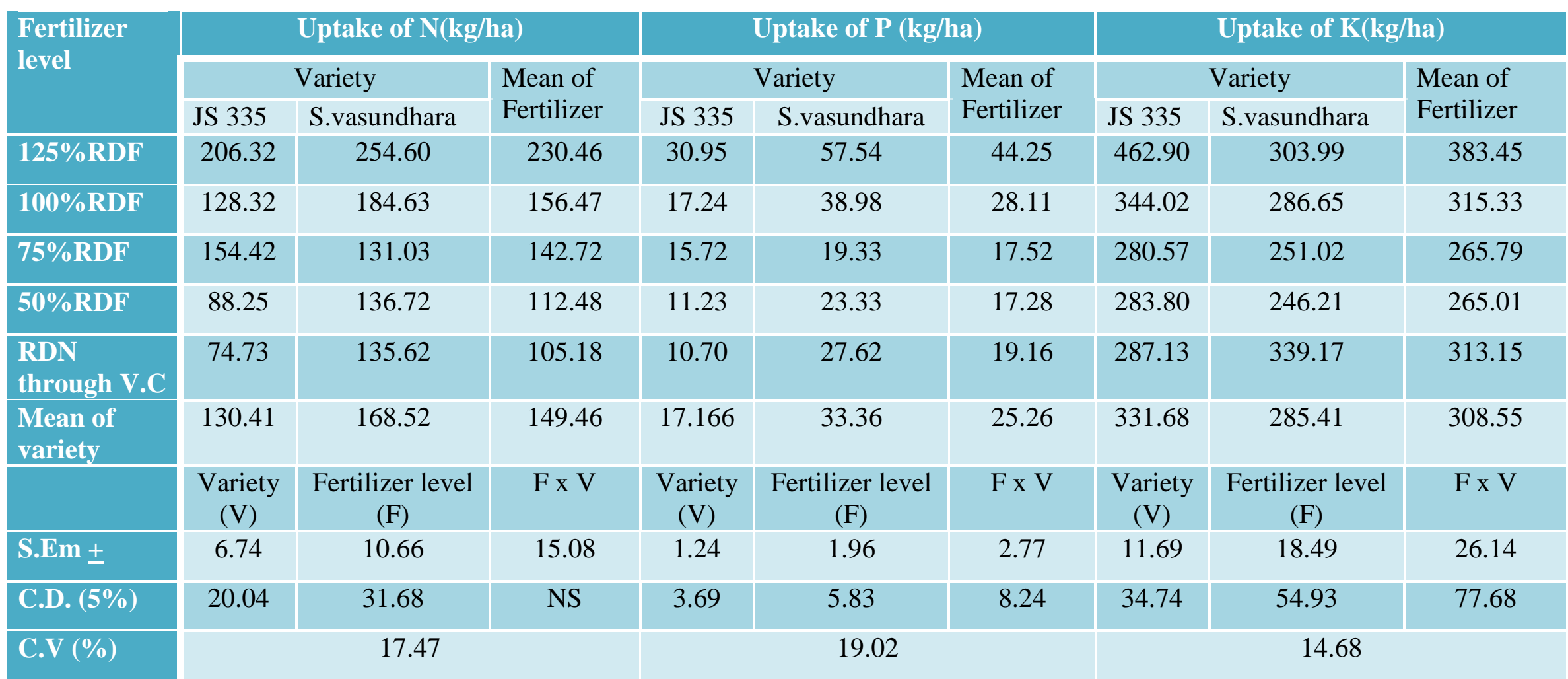

NS- Non-Significant

Table.2 Correlation between growth, yield, nutrient uptake and quality parameters

\begin{tabular}{|l|l|l|l|l|l|l|l|l|l|l|l|}
\hline & Height & $\begin{array}{c}\text { No. of } \\
\text { leaves }\end{array}$ & LAI 60 & LAI 75 & $\begin{array}{c}\text { No.of } \\
\text { pods }\end{array}$ & TDM & $\begin{array}{c}\text { pod } \\
\text { yield }\end{array}$ & $\begin{array}{c}\text { seed } \\
\text { yield }\end{array}$ & $\begin{array}{c}\text { Stover } \\
\text { yield }\end{array}$ & HI & Protein \\
\hline N uptake & $0.80^{*}$ & $0.70^{*}$ & $0.70^{*}$ & 0.22 & -0.08 & 0.60 & 0.07 & 0.09 & $0.92^{*}$ & $-0.65^{*}$ & -0.03 \\
\hline P uptake & $0.71^{*}$ & 0.45 & 0.45 & 0.01 & -0.38 & 0.31 & -0.26 & -0.23 & $0.89^{*}$ & $-0.81^{*}$ & -0.23 \\
\hline K uptake & $0.77^{*}$ & $0.72^{*}$ & 0.58 & $0.74^{*}$ & $0.68^{*}$ & 0.59 & $0.68^{*}$ & $0.74^{*}$ & 0.40 & 0.11 & $0.66^{*}$ \\
\hline
\end{tabular}

$*=$ significant at $5 \%(\mathrm{r}=0.602)$ 
Table.3 Effect of variety and fertilizer levels on Internal utilization efficiency ( $\mathrm{kg} \mathrm{pod} / \mathrm{kg}$ nutrient) of nutrients

\begin{tabular}{|c|c|c|c|c|c|c|c|c|c|}
\hline \multirow[t]{3}{*}{ Fertilizer level } & \multicolumn{3}{|c|}{ Nitrogen } & \multicolumn{3}{|c|}{ Phosphorus } & \multicolumn{3}{|c|}{ Potassium } \\
\hline & \multicolumn{2}{|c|}{ Variety } & \multirow{2}{*}{$\begin{array}{l}\text { Mean of } \\
\text { Fertilizer }\end{array}$} & \multicolumn{2}{|c|}{ Variety } & \multirow{2}{*}{$\begin{array}{l}\text { Mean of } \\
\text { Fertilizer }\end{array}$} & \multicolumn{2}{|c|}{ Variety } & \multirow{2}{*}{$\begin{array}{l}\text { Mean of } \\
\text { Fertilizer }\end{array}$} \\
\hline & JS335 & S.vasundara & & JS335 & S.vasundara & & JS335 & S.vasundara & \\
\hline $125 \% \mathrm{RDF}$ & 42.05 & 15.80 & 28.92 & 276.89 & 69.18 & 173.04 & 18.45 & 13.36 & 15.91 \\
\hline $100 \% \mathrm{RDF}$ & 62.34 & 21.16 & 41.75 & 495.67 & 100.11 & 297.89 & 23.48 & 13.54 & 18.51 \\
\hline 75\%RDF & 46.05 & 29.51 & 37.78 & 453.44 & 200.04 & 326.74 & 24.67 & 15.40 & 20.03 \\
\hline $50 \%$ RDF & 78.65 & 30.13 & 54.39 & 546.87 & 164.76 & 355.82 & 22.78 & 15.57 & 19.17 \\
\hline RDN through V.C & 52.43 & 30.66 & 41.54 & 393.00 & 156.45 & 274.72 & 13.91 & 11.61 & 12.76 \\
\hline \multirow{2}{*}{ Mean } & 56.30 & 25.45 & 40.88 & 433.18 & 138.11 & 285.64 & 20.66 & 13.89 & 17.28 \\
\hline & $\begin{array}{l}\text { Variety } \\
\text { (V) }\end{array}$ & $\begin{array}{l}\text { Fertilizer level } \\
\text { (F) }\end{array}$ & $\mathrm{F} \times \mathrm{V}$ & $\begin{array}{l}\text { Variety } \\
\text { (V) }\end{array}$ & $\begin{array}{l}\text { Fertilizer level } \\
\text { (F) }\end{array}$ & $\mathrm{F} \times \mathrm{V}$ & $\begin{array}{c}\text { Variety } \\
\text { (V) }\end{array}$ & $\begin{array}{l}\text { Fertilizer level } \\
\text { (F) }\end{array}$ & $\mathrm{F} \times \mathrm{V}$ \\
\hline S.Em + & 3.65 & 5.78 & 8.17 & 22.76 & 35.99 & 50.9 & 0.85 & 1.34 & 1.9 \\
\hline C.D. $(5 \%)$ & 10.86 & 17.17 & NS & 67.64 & 106.94 & 151.24 & 2.53 & 3.99 & 5.65 \\
\hline C.V (\%) & \multicolumn{3}{|c|}{25.23} & \multicolumn{3}{|c|}{17.14} & \multicolumn{3}{|c|}{19.06} \\
\hline
\end{tabular}

Table.4 Effect of varieties and fertilizer levels on post-harvest soil nutrient content

\begin{tabular}{|c|c|c|c|c|c|c|c|c|c|}
\hline \multirow{3}{*}{$\begin{array}{l}\text { Fertilizer } \\
\text { level }\end{array}$} & \multicolumn{3}{|c|}{$\mathbf{N}$ content (kg/ha) } & \multicolumn{3}{|c|}{ P content (kg/ha) } & \multicolumn{3}{|c|}{ K content (kg/ha) } \\
\hline & \multicolumn{2}{|c|}{ Variety } & \multirow{2}{*}{$\begin{array}{l}\text { Mean of } \\
\text { Fertilizer }\end{array}$} & \multicolumn{2}{|r|}{ Variety } & \multirow{2}{*}{$\begin{array}{l}\text { Mean of } \\
\text { Fertilizer }\end{array}$} & \multicolumn{2}{|r|}{ Variety } & \multirow{2}{*}{$\begin{array}{l}\text { Mean of } \\
\text { Fertilizer }\end{array}$} \\
\hline & JS335 & S.vasundara & & JS335 & S.vasundara & & JS335 & S.vasundara & \\
\hline $125 \%$ RDF & 413.97 & 329.27 & 371.62 & 44.20 & 41.33 & 42.77 & 395.10 & 384.17 & 389.64 \\
\hline $100 \%$ RDF & 347.40 & 311.93 & 329.67 & 41.08 & 35.33 & 38.21 & 348.44 & 355.80 & 352.12 \\
\hline $75 \%$ RDF & 294.44 & 265.90 & 280.17 & 35.13 & 30.68 & 32.90 & 306.03 & 335.17 & 320.60 \\
\hline $50 \%$ RDF & 281.77 & 216.33 & 249.05 & 32.70 & 24.33 & 28.52 & 318.23 & 285.33 & 301.78 \\
\hline Organic & 259.59 & 245.00 & 252.29 & 23.22 & 21.65 & 22.44 & 307.49 & 320.33 & 313.91 \\
\hline \multirow[t]{2}{*}{ Mean } & 319.43 & 273.68 & 296.56 & 35.267 & 30.67 & 32.97 & 335.06 & 336.16 & 335.61 \\
\hline & $\begin{array}{l}\text { Variety } \\
(\mathrm{V})\end{array}$ & $\begin{array}{l}\text { Fertilizer level } \\
\text { (F) }\end{array}$ & $\mathrm{F} \times \mathrm{V}$ & $\begin{array}{l}\text { Variety } \\
\text { (V) }\end{array}$ & $\begin{array}{l}\text { Fertilizer level } \\
\text { (F) }\end{array}$ & $\mathrm{F} \times \mathrm{V}$ & $\begin{array}{l}\text { Variety } \\
\text { (V) }\end{array}$ & $\begin{array}{l}\text { Fertilizer level } \\
\text { (F) }\end{array}$ & $\mathrm{F} \times \mathrm{V}$ \\
\hline S.Em \pm & 5.85 & 9.26 & 13.09 & 1.47 & 2.3 & 3.29 & 8.49 & 13.43 & 18.99 \\
\hline C.D. $(5 \%)$ & 17.39 & 27.5 & NS & 4.38 .0 & 6.92 & NS & NS & 39.9 & NS \\
\hline C.V (\%) & & 7.65 & & & 17.3 & & & 9.8 & \\
\hline
\end{tabular}

NS- Non-Significant 
Table.5 Net gain/loss of major nutrients in soil

\begin{tabular}{|c|c|c|c|c|c|c|c|c|c|}
\hline \multirow[t]{2}{*}{ Fertilizer levels } & \multicolumn{3}{|c|}{$\begin{array}{l}\text { Initial soil nutrient status } \\
\qquad(\mathrm{kg} / \mathrm{ha})(\mathrm{A})\end{array}$} & \multicolumn{3}{|c|}{$\begin{array}{l}\text { post harvest soil nutrients } \\
\text { status (kg/ha) (B) }\end{array}$} & \multicolumn{3}{|c|}{ Net gain/Loss (kg/ha) (B-A) } \\
\hline & $\mathrm{N}$ & $\mathrm{P}_{2} \mathrm{O}_{5}$ & $\mathrm{~K}_{2} \mathrm{O}$ & $\mathrm{N}$ & $\mathrm{P}_{2} \mathrm{O}_{5}$ & $\mathrm{~K} 2 \mathrm{O}$ & $\mathrm{N}$ & $\mathrm{P}_{2} \mathrm{O}_{5}$ & $\mathrm{~K}_{2} \mathrm{O}$ \\
\hline $125 \% \mathrm{RDF}$ & 353.19 & 23.83 & 317.5 & 413.97 & 44.2 & 395.1 & 60.78 & 20.37 & 77.6 \\
\hline $100 \% \mathrm{RDF}$ & 353.19 & 23.83 & 317.5 & 347.4 & 41.08 & 348.44 & -5.79 & 17.25 & 30.94 \\
\hline $75 \%$ RDF & 353.19 & 23.83 & 317.5 & 294.44 & 35.13 & 306.03 & -58.75 & 11.3 & -11.47 \\
\hline $50 \%$ RDF & 353.19 & 23.83 & 317.5 & 281.77 & 32.7 & 318.23 & -71.42 & 8.87 & 0.73 \\
\hline RDN through V.C & 353.19 & 23.83 & 317.5 & 259.59 & 23.22 & 307.49 & -93.6 & -0.61 & -10.01 \\
\hline $125 \%$ RDF & 353.19 & 23.83 & 317.5 & 329.27 & 41.33 & 384.17 & -23.92 & 17.5 & 66.67 \\
\hline $100 \%$ RDF & 353.19 & 23.83 & 317.5 & 311.93 & 35.33 & 355.8 & -41.26 & 11.5 & 38.3 \\
\hline $75 \% \mathrm{RDF}$ & 353.19 & 23.83 & 317.5 & 265.9 & 30.68 & 335.17 & -87.29 & 6.85 & 17.67 \\
\hline $50 \%$ RDF & 353.19 & 23.83 & 317.5 & 216.33 & 24.33 & 285.33 & -136.86 & 0.5 & -32.17 \\
\hline RDN through V.C & 353.19 & 23.83 & 317.5 & 245 & 21.65 & 320.33 & -108.19 & -2.18 & 2.83 \\
\hline
\end{tabular}




\section{Post-harvest residual soil nutrient content and net gain/loss}

The residual $\mathrm{N}$ and $\mathrm{P}$ content in soil after harvest of the soybean was significantly influenced by fertilizer levels, varieties, but their interaction did not influence significantly (Table 4). Among the varieties, significantly higher residual $\mathrm{N}$ and $\mathrm{P}$ content in soil (319.43 and $35.267 \mathrm{~kg} / \mathrm{ha}$ respectively) was recorded in JS-335 as compared to Swarna vasundhara (273.68 and $30.66 \mathrm{~kg} / \mathrm{ha})$. With respect to residual $\mathrm{K}$ there was no significant difference between varieties. Among the fertilizer levels, application of 125 per cent RDF recorded significantly higher residual $\mathrm{N}, \mathrm{P}$ and $\mathrm{K}$ (371.62, 42.77 and $389.64 \mathrm{~kg} / \mathrm{ha}$ respectively) content in soil over all other treatments. Potassium has a positive effect on nitrogen fixation and nitrogen accumulation in the legumes.

Hence application of potassium more than recommended might have enhanced the nodulation and nitrogen fixation resulting in enhanced nitrogen availability to plant as a result more balance $\mathrm{N}$ left in soil after harvest of plant. This is very well reflected in lower post-harvest soil $\mathrm{N}$ content in 100 per cent RDF $(329.7 \mathrm{~kg} / \mathrm{ha})$ compared to initial status $(353.2 \mathrm{~kg} / \mathrm{ha})$ and it has increased $(371.6 \mathrm{~kg} / \mathrm{ha})$ with 125 per cent RDF. Among the treatment combination, variety JS 335 with 125 per cent RDF recorded maximum post-harvest soil N, P and $\mathrm{K}$ content $(413.97,44.2$ and $395.1 \mathrm{~kg} / \mathrm{ha}$ ) indicating a net gain of $60.78,20.37$ and 77.6 $\mathrm{kg} \mathrm{N}, \mathrm{P}$ and $\mathrm{K} /$ ha respectively (Table 5). However with respect to other treatment combinations net gain/loss of nutrient was negative in most cases. Only JS 335 with 125 per cent RDF showed a higher post-harvest residual soil nutrient content indicating the need of balanced nutrition for soil health sustainability. Similar result was reported by Vyas and Kushwah (2015) in a study on response of soybean varieties to fertilizer levels in Madhya Pradesh.

Irrespective of variety, with increase in fertilizer level, there was a increase in post-harvest soil available $\mathrm{P}$ compared to initial soil $\mathrm{P}$ status indicating a positive gain. This may be due to addition of adequate amount of $\mathrm{P}$ through fertilizer and considerable amount of unutilized $P$ left in the soil. Soils of Karnataka being alkaline in nature the unutilized $\mathrm{P}$ was fixed by the calcium and calcium carbonate present in the soil resulting in buildup of soil P. Similar results of positive net gain was reported by Vyas and Kushah (2015) with increased fertilizer application in soybean. No appreciable decline in post-harvest $\mathrm{P}$ status was observed with 100 per cent RDN through vermicompost added treatments. This was owing to the improvement in soil health, reduced $\mathrm{P}$ fixation and increase in available phosphorus content of soil due to release of $\mathrm{CO}_{2}$ and organic acids during decomposition, which helped in solubilising the native soil $\mathrm{P}$ as a result increased the availability of native as well as applied phosphorus. Results corroborate the findings of Govindan and Thrimurugan (2005).

The significant and progressive increase in postharvest available $\mathrm{K}$ content of the soil was observed with corresponding increase in fertilizer levels. Increased level of $\mathrm{K}$ ensured the availability of $\mathrm{K}$ in adequate quantity to soybean plant and balance left out in the soil enhanced the post-harvest $\mathrm{K}$ in the soil. On the other hand 50 per cent RDF could not meet the plant requirement leading to utilization of $\mathrm{K}$ from soil pool resulting in decline of soil $\mathrm{K}$ compared to initial status resulted in negative or no net gain in $\mathrm{K}$ status. Similarly Vyas and Kushwah (2015) also reported progressive increase in post-harvest $\mathrm{K}$ status with highest level of $\mathrm{K}$ application in soybean.

Post-harvest soil nutrient status varied significantly between variety with Swarna Vasundhara recording significantly lower nutrient particularly $\mathrm{N}$ and $\mathrm{P}$ compared to JS 335 . This may be attributed to the significantly higher nutrient content and uptake as well as higher stover yield recorded with Swarna vasundhara resulting in more removal of nutrient from soil leading to decline of nutrient status after the harvest of soybean. This 
indicates that Swarna Vasundhara variety needs different levels of fertilizer with more balanced nutrient supply along with other micronutrient to enhance the efficiency and yield level.

Nutrient management plays a significant role in nutrient uptake, utilization efficiency and soil fertility maintenance. Vegetable soybean variety Swarna vasundhara showed significantly higher nutrient uptake at 125 per cent RDF but showed poor internal utilization efficiency (IE) compared to JS 335 resulting in low yield.

Low IE by Swarna vasundhara indicate imbalance in nutrient level suggesting the need for modifying the seed soybean fertilizer dose to meet the specific nutrient requirement of vegetable soybean. Similarly post-harvest soil nutrient status with vegetable soybean at all the levels of fertilizer dose was negative compared to JS 335 with 125 per cent RDF indicating the need for different fertilizer level with more balanced supply to enhance the yield and maintain the soil health in sustained manner.

\section{References}

Dobermann, A. 2007. Nutrient use efficiencymeasurement and management. In "IFA Internation al Workshop on Fertilizer Best Management Practices," Brussels, Belgium, p1-28.

Govindan, K. and Thirumurugan, 2005, Synergistic association of rhizobium with phosphate solubilizing bacteria under different sources of nutrient supply on productivity and soil fertility in soybean (Glycine max). Indian Journal of Agronomy, 50 (3): 214-217.

Meena, D. S., Ram, B. and Jadon, C., 2016, Effect of integrated nutrient management on productivity, profitability, nutrient uptake and soil fertility in soybean [Glycine max (L.) Merrill]. Soybean Research, 14(1): 21-33.

Prasad, J. and Sanoria, C. C., 1981, Response of Bengal gram to seed bacterization and phosphorus. Seed and Farms, 7(4): 31-82.

Sharma, R. A. and Dixit, B. K., 1987, Effect of nutrient application on rainfed soybean. Journal of Indian Society of Soil Science, 35: 452-455.

Subbaiah, B. V. and Asija, C. C., 1956, A rapid procedure for estimation of available nitrogen in soils. Current Science, 25: 259-260.

UAS Dharwad, 2016. University of Agriculture Sciences Dharwad Package of Practices, 2016, pp 169-176. (https:// drive.google.com/file/ d/0B0MAv TXVwzUKdj FMZTZWam JRc3c/view accessed on 10-08-2017)

Vijayalakshmi Patil, S. Meti, C. P. Mansur, E. Rajashekhara, Itagi Prabhaker, H. P. Hadimani and Kaviraja H. 2017. Nutritional Studies on Vegetable Soybean [Glycine $\max (\mathrm{L}$.$) Merrill], in northern$ dryzone of Karnataka, India. Int. J. Curr. Microbiol. App. Sci. 6(12): 5364-5374. doi:

https://doi.org/10.20546/ijcmas.2017.612. 501

Vyas, A. K., Billore, S. D., Joshi, O. P. and Pachlania, N. K., 2007, Influence of balanced nutrition on productivity of soybean. Soybean Research, 5: 21-25.

Walkley, A. J. and Black, C.A., 1934. An examination of the method for determining soil organic matter and a proposed modification of the chromic acid titration method. Soil Science, 37: 29-38.

\section{How to cite this article:}

Vijayalakshmi Patil, Shankar Meti, M. S. Nagaraja, E. Rajashekar and Mansur C. P. 2018. Response of Soybean to Fertilizer Levels in Northern Dry Zone of Karnataka, India. Int.J.Curr.Microbiol.App.Sci. 7(07): 4297-4307. doi: https://doi.org/10.20546/ijcmas.2018.707.501 